\title{
Simulation of agro-ecosystem service value in oasis area of lower reaches of Tarim River
}

\author{
hongwei li $^{1}$ and yaning Chen $^{2}$ \\ ${ }^{1}$ Xinjiang University \\ ${ }^{2}$ Xinjiang Institute of Ecology and Geography, Chinese Academy of Sciences, Urumqi,
}

September 24, 2021

\begin{abstract}
Based on the relationship between the service value of each component of agro-ecosystem and its corresponding land cover, the service value of agro-ecosystem in oasis area of lower reaches of Tarim River was analyzed. Using the land cover data of 2000, 2010 and 2020, and setting two scenarios in the FLUS model to simulate the land cover change of the study area in 2030. According to the forecast results of land cover, the the value of agro-ecological service was calculated and the sensitivity was analyzed. Results showed the following: (1) The Kappa coefficients and overall accuracy of 2010 land cover models simulated by FLUS are 0.8429 and $92.55 \%$, indicating that the model has appropriate simulation accuracy. (2) The proportion of farmland, grassland, water body and artificial surface increased from $4.28 \%, 22.26 \%, 2.18 \%$ and $1.16 \%$ in 2000 to $6.63 \%, 25.86 \%, 10.96 \%$ and $0.48 \%$ in 2030 benchmark scenario, respectively. On the contrary, the shrub land and barren land decreased from $1.07 \%$ and $70.75 \%$ in 2000 to $0.7 \%$ and $55.44 \%$ in 2030 benchmark scenario, respectively.(3) The agro-ecosystem service value of benchmark scenario and ecological protection scenario are CN¥6.781×109 and CN¥6.937×109 in 2030, respectively. The practice has proved that the ecological water conveyance project is very necessary to improve the agricultural ecological environment in oasis area of lower reaches of Tarim River. This study can provide reference for the research on the agro-ecosystem service value of oases in inland river basins of China and Central Asia.
\end{abstract}

\section{Hosted file}

ESV.docx available at https://authorea.com/users/435653/articles/538524-simulation-of-agroecosystem-service-value-in-oasis-area-of-lower-reaches-of-tarim-river

\section{Hosted file}

fig.docx available at https://authorea.com/users/435653/articles/538524-simulation-of-agroecosystem-service-value-in-oasis-area-of-lower-reaches-of-tarim-river 